\title{
Elevated Plasma High Sensitivity C-reactive Protein (hs-CRP) Level is a Predictor of Periprocedural Myocardial Injury during Percutaneous Coronary Intervention (PCl)
}

\author{
Mohsin Ahmed ${ }^{1}$, Nazir Ahammed Chowdhury², Afzalur Rahman ${ }^{3}$, Mostafizur Rahman $^{4}$, \\ Mohammed Gaffar Amin ${ }^{5}$, Sufia Jannat ${ }^{6}$, Rakibul Islam Mollah ${ }^{7}$
}

\section{Abstract:}

Background: Elevated high sensitivity C-reactive protein (hs-CRP) has been well known as a biomarker reflecting inflammatory process for prediction of ischemic events among patients with coronary artery disease. Relatively small studies have identified a heightened and sustained inflammatory response after percutaneous coronary intervention ( $\mathrm{PCI}$ ) to be a predictor of periprocedural events after coronary angioplasty and a marker of increased restenosis risk among patients undergoing coronary stenting. Embolization of atherosclerotic and thrombotic debris can induce myocardial necrosis during $\mathrm{PCl}$. This study was designed to evaluate whether pre procedural hs-CRP level is associated with procedure related distal microembolization producing myocardial injury (assessed by CK-MB level) after PCI.

Methods: A total of $\mathbf{3 1 0}$ patients with chronic stable angina and unstable angina, who would undergo elective $\mathrm{PCl}$ were evaluated in National Institute of Cardiovascular Disease (NICVD), Dhaka with a view to evaluate the relationship between preprocedural hs-CRP and rise of CK-MB level, before and after PCI. Patients were divided in 2 groups according to hs-CRP: Group I = hs-CRP $<3$ $\mathrm{mg} / \mathrm{L}$, Group II = hs-CRP $\geq 3 \mathrm{mg} / \mathrm{L}$.

1. Associate Professor, Department of Cardiology, Dhaka Medical College and Hospital, Dhaka, E-mail: mohsinsohel07@gmail.com

2. Professor, Department of Cardiology, National Institute of Cardiovascular Disease, Dhaka.

3. Professor, Department of Cardiology, National Institute of Cardiovascular Disease, Dhaka

4. Junior Consultant, Upazila Health Complex, Rupgang, Naryanganj.

5. Department of Cardiology, Dhaka Medical College and Hospital, Dhaka.

6. Medical Officer, Upazila Health Complex, Daudkandi, Comilla.

7. Assistant Registrar, Department of Cardiology, National Institute of Cardiovascular Disease, Dhaka.
Results: A total of 310 patients were divided into two groups: Normal CRP group $(n=131)$ and elevated CRP group ( $n=179$ ). Following $\mathrm{PCl}, \mathrm{CK}-\mathrm{MB}$ level rose from baseline in both groups. In normal CRP group, there was no significant elevation of CK-MB level after $\mathrm{PCl}$ (Pre-procedural vs. Post-procedural: 18.6 \pm 5.4 vs. $29.1 \pm$ $5.6 \mathrm{mg} / \mathrm{L}, \mathrm{p}=\mathrm{ns}$ ). In elevated CRP group, there was significant elevation of CK-MB level after PCI (Preprocedural vs. Post-procedural: $19.1 \pm 6.7$ vs. $52.46 \pm 9.4$ $\mathrm{mg} / \mathrm{L}, \mathrm{p}<0.01)$. The mean rise of CK-MB level was higher in group II than group I (33.06 $\pm 11.62 \mathrm{U} / \mathrm{L}$ vs. 11.52 $\pm 9.60 \mathrm{U} / \mathrm{L})$. The findings were statistically significant between the study groups $(p>0.05)$. Also there was a positive linear correlation between preprocediral hsCRP level and rise of CKMB ( $r=0.22)$ following procedure and it was statistically significant $(p<0.05)$. Multivariate logistic regression analysis was done among traditional predictors of $\mathrm{PCl}$ outcome including advanced age ( $>50$ years), female gender, diabetes mellitus, BMI, hypertension, smoking, dylipidaemia, type C lesion, multiple stents, post dilatation and hsCRP. After removing the effects of the all other variables, hs- CRP was independent predictor of periprocedural myocardial injury during $\mathrm{PCI}$, assessed by $\mathrm{CK}-\mathrm{MB}$ elevation with OR 1.57 and $\mathrm{p}=0.001$.

Conclusion: The inflammatory activity, as represented by hs-CRP level, is associated with procedure related microvascular injury as assessed by CK-MB elevation after PCl. Measurement of hs-CRP levels could provide a rationale for risk stratification before coronary intervention and may be a useful tool to target aggressive antiaggregatory or anti-inflammatory therapy to patients that are exposed to the highest risk for ischemic complications. As distal microembolization is a determinant of short and long term mortality after $\mathrm{PCl}$, specific strategies may be developed to minimize myocardial injury in subjects with elevated hs-CRP level.

Key words: hs CRP, Periprocedural myocardial injury, PCI 


\section{Introduction:}

$\mathrm{PCl}$ has become one of the cardinal treatment strategies for stenotic coronary artery disease, over the past three decades.. Owing to improvement in interventional techniques and expertise as well as to the introduction of new devices such as stents, the incidence of major peri-procedural ischaemic complications (myocardial infarction, coronary artery bypass grafting, and cardiac death) was reduced from initially $9 \%$ to currently less than $2 \% .^{1.2}$ However, the incidence of post-procedural cardiac marker elevation has not substantially declined since its first serial assessment by Oh et al. in $1985 .^{3}$ These post-procedural cardiac marker elevations are considered to represent peri-procedural myocardial injury (PMI) with worse long-term outcome.

Since the last decade, systemic inflammatory markers have been carefully investigated; among these, several have been related to the risk of death, myocardial infarction, or restenosis after $\mathrm{PCl}$, but only C-reactive protein (CRP) has been consistently shown to significantly and independently confer an adverse prognosis in patients with coronary artery disease, including those undergoing $\mathrm{PCl}^{4-6}$ This is probably because of its relatively long half-life and chemical stability as well as the limited costs and logistic hurdles faced by clinicians willing to measure it. ${ }^{6}$ Increased C-reactive protein may become an important factor in pre-procedural risk stratification. As an independent marker for the rapid progression of atherosclerosis or the presence of an increased risk of subsequent adverse clinical outcome, increased C-reactive protein may identify high-risk patients as candidates for high dose lipid lowering therapy. ${ }^{7}$ Cardiac biomarkers have been extensively used in the past two decades to establish the incidence and the prognostic implication of PMI. Elevation of both creatine kinase-myocardial band isoform (CK-MB) and cardiac troponin has been associated with a worse short and long-term outcome. ${ }^{8-10}$ Although controversies regarding the prognostic significance of individual cardiac biomarkers persist, CK-MB elevation is widely accepted as a biomarker with prognostic significance when raised post-PCI. Elevation of CK-MB above the normal levels occurs in about $30 \%$ of patients undergoing elective $\mathrm{PCl} .{ }^{8}$ More than 60 studies in the past two decades have assessed the prognostic significance of elevations in total CK and/or CK-MB fraction following PCI. Metaanalyses evaluating the prognostic value of $\mathrm{CK}-\mathrm{MB}$ release during $\mathrm{PCl}$ have inferred the proportionate increase in the early and late mortality with increased CK-MB release peri-procedurally. ${ }^{11}$
Elevated high sensitivity C-reactive protein (hs-CRP) has been well known as a biomarker reflecting inflammatory process for prediction of ischemic events among patients with coronary artery disease. Relatively small studies have identified a heightened and sustained inflammatory response after $\mathrm{PCl}$ to be a predictor of periprocedural events after coronary angioplasty and a marker of increased restenosis risk among patients undergoing coronary stenting. Embolization of atherosclerotic and thrombotic debris can induce myocardial necrosis during PCls. This study was designed to evaluate whether pre procedural hs-CRP level is associated with procedure related distal microembolization producing myocardial injury (assessed by CK-MB level) after PCIs.

\section{Methods:}

This prospective, observational study was conducted in the National Institute of Cardiovascular Disease (NICVD), Dhaka from January 2012 to December 2013 with a view to evaluate the relationship between preprocedural hsCRP and rise of CK-MB level, before and after PCI. A total of 310 patients with chronic stable angina and unstable angina, who would undergo elective percutaneous coronary intervention were included and devided in 2 groups according to hs-CRP: Group I = hs-CRP $<3 \mathrm{mg} /$ L, Group II = hs-CRP $\geq 3 \mathrm{mg} / \mathrm{L}$.

\section{Laboratory Analysis:}

Peripheral blood samples for measurement of baseline $\mathrm{CK}-\mathrm{MB}$ and high sensitivity C-reactive protein was taken on the day before $\mathrm{PCl}$. C-reactive protein was assayed by latex-enhanced immune nephelometry on a Behring BN-Pro Spec Nephelometer (SIEMENS, USA). CK-MB levels also being measured at 8 hours and 24 hours after the procedure. The definition of PMI included any increase of CKMB more than one time the upper limit of normal (ULN). Moreover, according to the universal definition of myocardial infarction, $\mathrm{PCl}$-related myocardial infarction was defined only in case of an increase of CKMB more than three times ULN, whereas elevations of cardiac biomarkers between one and three times ULN were considered as indicative of periprocedural myocardial necrosis, but not infarction. ${ }^{12}$

\section{Angiographic Analysis:}

Coronary angiographic findings were recorded before balloon dilatation and after stenting and interpretation was done by one interventional cardiologist using standard protocol. In this study angiographic severity of coronary artery disease was assessed by vessel score, stenosis score, lesion morphology and TIMI flow grading. 
Vessel score ${ }^{13}$ : Score ranged from 0 to 4 , depending on the number of vessels involved with a significant stenosis. (50\% or greater luminal stenosis).

Stenosis score ${ }^{13}$ : The evaluation of degree of stenosis relates to the percentage reduction in the diameter of the vessel. By Gensini score, the lesions are roughly classified by visual estimation of reduction of luminal diameter.

Lesion morphology ${ }^{14}$ : Type A, Type B and Type C lesion established by a joint ACC/AHA task force.

Culprit artery TIMI flow ${ }^{14}$ : According to the TIMI grade flow in the culprit artery is defined by American College of Cardiology (TIMI Grade 0-3)

Percutaneous coronary intervention with stenting was carried out in an artery having $70 \%$ stenosis. Procedures were performed using standard angioplasty techniques, all patients received $600 \mathrm{mg}$ clopidogrel prior to $\mathrm{PCl}$ and 150 unit per kg body weight unfractionated heparin was used during the procedure in every patient. Angiographic success of $\mathrm{PCl}$ was defined as residual stenosis $<20 \%$, determined by visual estimation and Thrombolysis in Myocardial Infarction grade $3{ }^{15}$ Procedural success was defined as achievement of angiographic success without major clinical complications (e.g. death, MI, emergency coronary artery bypass surgery) during hospitalization. ${ }^{15}$

\section{Statistical Analysis:}

Continuous baseline variables with normal distribution were expressed as mean \pm SD and were compared by ttest. Categorical variables were compared by Fisher exact test or chi-square test where appropriate. Multiple logistic regression analysis was performed to establish the independent predictive value of pre-procedural C-reactive protein in addition to other traditional prognostic risk factors (control of confounding). The statistical analysis was performed using the Statistical Package for Social Sciences software (SPSS). A p-value $<0.05$ was considered statistically significant.

\section{Results:}

A total of 310 patients with chronic stable angina and unstable angina, who would undergo elective percutaneous coronary intervention were included and devided in 2 groups according to hs-CRP: Group I = hsCRP $<3 \mathrm{mg} / \mathrm{L}$ included 131 patients (42\%) and Group II = hs-CRP $\geq 3 \mathrm{mg} / \mathrm{L}$ included 179 patients (58\%). The mean $( \pm S D)$ age of the patients was $51 \pm 6.93$ years and $53 \pm 6.04$ years in group I and group II respectively, no significant difference was found between two groups. Most of the patients were in 5th decade of life in both groups. Male sex predominated in both groups, malefemale ratio was 2.5-2.7:1 and no significant $(p=0.55)$ difference was found between two groups.
Regarding risk factors, patients with high preprocedural hsCRP had highest percentage of smoking (62\%),followed by diabetes mellitus (55\%), hypertension (45\%), dyslipidemia(36\%), and family h/o premature coronary artery disease(11\%). Similarly among patients with normal preprocedural hsCRP group, smokers were predominant (58\%), followed by diabetes mellitus (52\%) hypertension (42\%), dyslipidemia (32\%), and family history of premature coronary artery disease (9\%). Cross tab analysis found no statistically significant differences between two groups $(p>0.05)$. We included patients with chronic stable angina and unstable angina which was $46 \%$ and $54 \%$ respectively in group I and $48 \%$ and $52 \%$ respectively in group II. The difference was not significant statistically ( $p>$.05). Mean preprocedural hsCRP was 6.1 \pm 2.4 and $1.2 \pm 0.7$ respectively among the groups and the difference was significant statistically $(p<0.05)$.

Table-I

Distribution of baseline characteristics among the study group

\begin{tabular}{|c|c|c|c|c|c|}
\hline \multicolumn{3}{|c|}{ Characteristics } & $\begin{array}{c}\text { Group I* } \\
\text { No (percent) }\end{array}$ & $\begin{array}{c}\text { Group II* } \\
\text { No (percent) }\end{array}$ & $P$ value \\
\hline \multicolumn{3}{|c|}{ Age (Mean \pm SD) } & $51 \pm 6.93$ & $53 \pm 6.04$ & $0.82\left(\mathrm{NS}^{*}\right)$ \\
\hline \multirow[t]{2}{*}{ Sex } & Male & & $96(73 \%)$ & 127 (71\%) & $0.84(\mathrm{NS})$ \\
\hline & Female & & $35(27 \%)$ & $51(29 \%)$ & 0.62 (NS) \\
\hline \multicolumn{3}{|c|}{ Smoking } & $75(58 \%)$ & $110(62 \%)$ & $0.64(\mathrm{NS})$ \\
\hline \multicolumn{3}{|c|}{ Diabetes } & $68(52 \%)$ & 101(55\%) & $0.63(\mathrm{NS})$ \\
\hline \multicolumn{3}{|c|}{ Hypertension } & $55(42 \%)$ & $81(45 \%)$ & 0.59 (NS) \\
\hline \multicolumn{3}{|c|}{ Dyslipidaemia } & $42(32 \%)$ & $65(36 \%)$ & $0.54(\mathrm{NS})$ \\
\hline \multicolumn{3}{|c|}{ BMI (Mean \pm SD) } & $23.86 \pm 1.73$ & $26.43 \pm 2.69$ & 0.29 (NS) \\
\hline \multicolumn{3}{|c|}{ Family history of IHD } & $11(9 \%)$ & $21(11 \%)$ & $0.32(\mathrm{NS})$ \\
\hline \multirow{2}{*}{\multicolumn{2}{|c|}{ Clinical pattern }} & $\begin{array}{l}\text { Unstable } \\
\text { Angina }\end{array}$ & $71(54 \%)$ & $93(52 \%)$ & 0.78 (NS) \\
\hline & & $\begin{array}{l}\text { Chronic } \\
\text { Stable } \\
\text { Angina }\end{array}$ & $60(46 \%)$ & $86(48 \%)$ & 0.79 (NS) \\
\hline
\end{tabular}

* Group I = hs-CRP $<3 \mathrm{mg} / \mathrm{L}$, * Group II = hs-CRP $\geq 3 \mathrm{mg} / \mathrm{L}, \mathrm{NS}=$ Not significant

Baseline characteristics had no statistically significant difference between the groups. (Table-I).

Table-II

Angiographic characteristics among the study group

\begin{tabular}{lccc}
\hline Variables & Group- I* & Group-II* & p-value \\
\hline Vessel score & $1.74 \pm 0.46$ & $2.24 \pm 0.78$ & $0.64\left(\mathrm{NS}^{\star}\right)$ \\
Stenosis score & $11.00 \pm 4.19$ & $18.72 \pm 4.94$ & $0.52(\mathrm{NS})$ \\
Multivessel Disease $\%$ & $35 \%$ & $42 \%$ & $0.12(\mathrm{NS})$ \\
$\begin{array}{l}\text { Complex Lesion } \\
\text { (Type B \& C)\% }\end{array}$ & $31 \%$ & $52 \%$ & $0.04(\mathrm{~S})$ \\
LM disease (\%) & $9 \%$ & $8 \%$ & $0.72(\mathrm{NS})$ \\
\hline
\end{tabular}

${ }^{*}$ Group I = hs-CRP $<3 \mathrm{mg} / \mathrm{L}$, * Group II $=$ hs-CRP $\geq 3 \mathrm{mg} / \mathrm{L}, \mathrm{NS}=$ Not significant, $\mathrm{S}=$ Significant. 
Angiographic severity was assessed by vessel score, stenosis, lesion morphology and TIMI flow grading. Vessel score (1.74 \pm 0.46 vs. $2.24 \pm 0.78)$, stenosis score $(11.00 \pm 4.19$ vs. and 18.72 \pm 4.94$)$ and multivessel disease (35\% vs. $42 \%$ ) and LM disease (9\% vs. $8 \%$ ) had no statistically significant difference between two groups. Complex lesions (Type B \& C) were $31 \%$ in group I and $52 \%$ in group II respectively and the difference was statistically significant $(P<.05)$. (Table $-I$, Fig.-1,2,3).

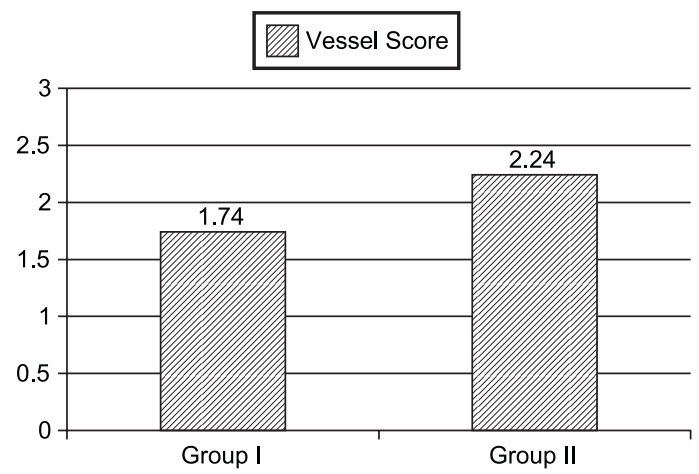

Fig.-1: Vessel score in relation to study groups.

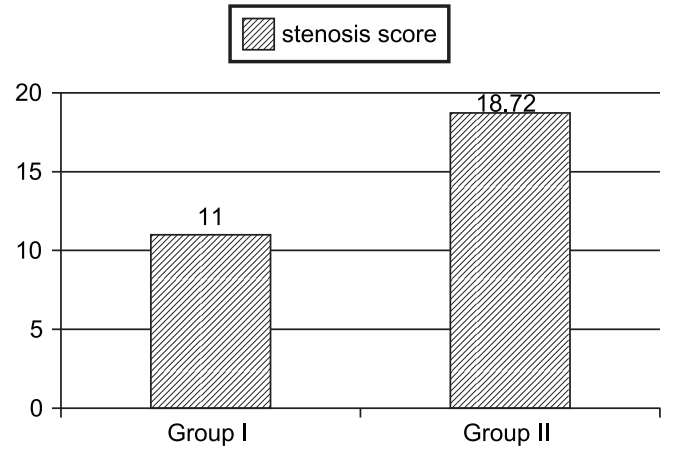

Fig.-2: Stenosis score in relation to study groups.

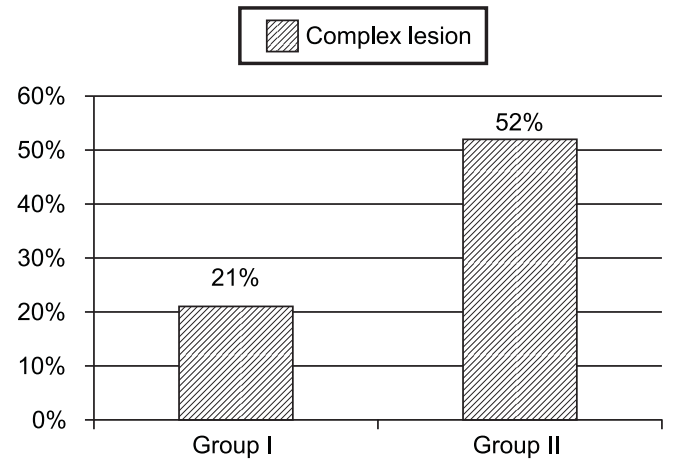

Fig.-3: Morphology of the lesion in relation to study group.
Table-III

Comparison of pre and post PCI CK-MB changes of the study population

\begin{tabular}{lccccc}
\hline $\begin{array}{l}\text { Study } \\
\text { Group }\end{array}$ & $\begin{array}{c}\text { Baeline } \\
\text { CK-MB } \\
\text { level }\end{array}$ & $\begin{array}{c}\text { CK-MB level } \\
\text { 24 CKMB } \\
\text { level hours } \\
\text { after PCl }\end{array}$ & p-value & $\begin{array}{c}\text { Mean } \\
\text { increase of }\end{array}$ & p-value \\
\hline Group- I & $18.6 \pm 5.4$ & $29.1 \pm 5.6$ & $0.64\left(\mathrm{NS}^{*}\right)$ & $11.52 \pm 9.60$ & $0.01\left(\mathrm{~S}^{*}\right)$ \\
Group- II & $19.1 \pm 6.7$ & $52.46 \pm 9.4$ & $0.01(\mathrm{~S})$ & $33.06 \pm 11.62$ & \\
\hline * Group I = hs-CRP <3 mg/ L, * Group II = hs-CRP $\geq 3 \mathrm{mg} / \mathrm{L}, \mathrm{NS}=\mathrm{Not}$ \\
significant, S= Significant.
\end{tabular}

Following $\mathrm{PCl}, \mathrm{CK}-\mathrm{MB}$ level was raised from baseline in both groups. In normal CRP group, there was no significant elevation of CK-MB level after PCl (Pre-procedural vs. Postprocedural: $18.6 \pm 5.4$ vs. $29.1 \pm 5.6 \mathrm{mg} / \mathrm{L}, \mathrm{p}=0.64)$. In elevated CRP group, there was significant elevation of CK-MB level after $\mathrm{PCl}$ (Pre-procedural vs. Post-procedural: $19.1 \pm 6.7$ vs. $52.46 \pm 9.4 \mathrm{mg} / \mathrm{L}, \mathrm{p}=0.01$ ). (Table $-\mathrm{III}$, Figure -4$)$. The mean rise of CK-MB level was significantly higher in group II than group I $(33.06 \pm 11.62 \mathrm{U} / \mathrm{L}$ vs. $11.52 \pm 9.60 \mathrm{U} / \mathrm{L}, \mathrm{p}=0.01)$. (Table $-\mathrm{III}$, Figure -5 ).

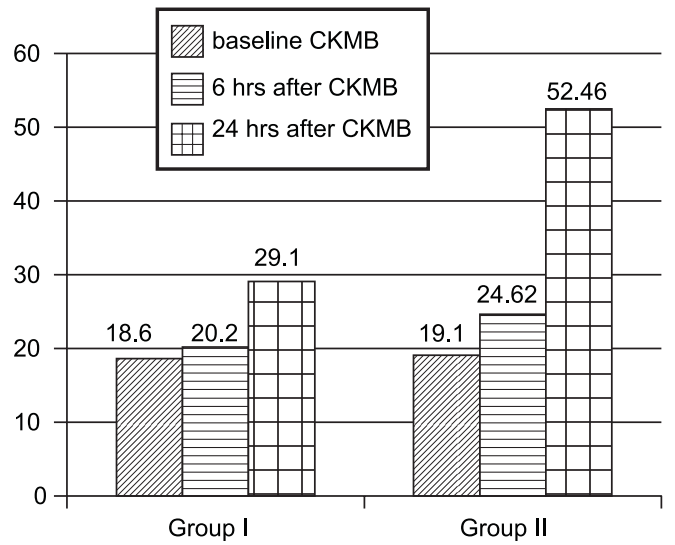

Fig.-4: Periprocedural CKMB changes in relation to study group.

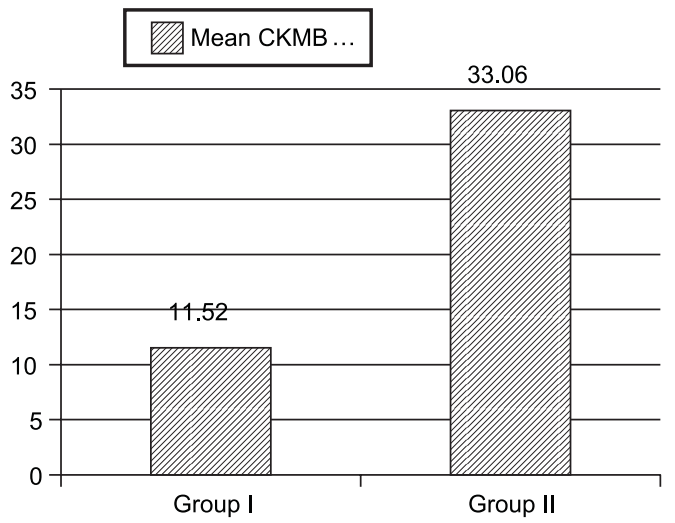

Fig.-5: Periprocedural mean CKMB elevation in relation to study group. 


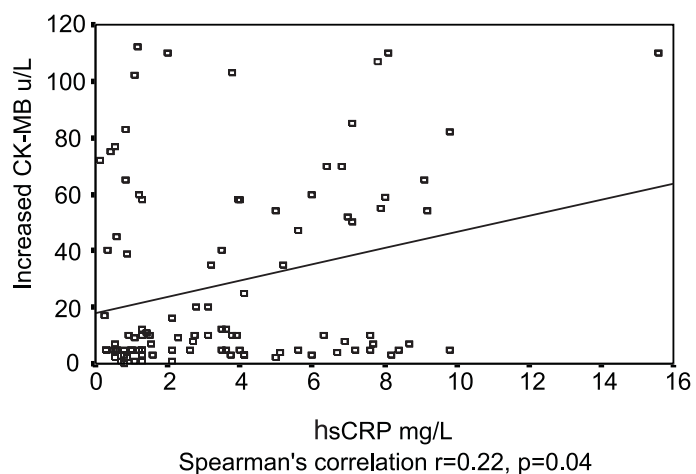

Fig.-6: Correlation between hsCRP and increased CKMB $u / L$

The figure - 6 showed that there was a linear positive correlation between hsCRP and increased CKMB u/L ( $r$ $=0.22)$ which was statistically significant $(p=0.04)$.

Table-IV

Comparison of study group according to development of periprocedural myocardial injury

\begin{tabular}{|c|c|c|c|}
\hline $\begin{array}{l}\text { Periprocedural } \\
\text { myocardial injury }\end{array}$ & $\begin{array}{c}\text { Group- I* } \\
\text { No (percent) }\end{array}$ & $\begin{array}{c}\text { Group-II* } \\
\text { No (percent) }\end{array}$ & $\mathrm{p}$-value \\
\hline Periprocedural MI & $2(1.5 \%)$ & $12(6.7 \%)$ & $0.04\left(S^{*}\right)$ \\
\hline $\begin{array}{l}\text { Periprocedural } \\
\text { myocardial necrosis }\end{array}$ & $7(5.3 \%)$ & $38(21.2 \%)$ & $0.01(S)$ \\
\hline
\end{tabular}

Periprocedural MI was found in $12(6.7 \%)$ patients in group II and 2(1.5\%) in group I, and the difference was significant statistically $(p=0.04)$. Periprocedural myocardial necrosis was found in 7 (5.3\%) patients in group I and 38(21.2\%) in group II, and the difference was significant statistically $(p=0.01)$. (Table-IV)

Table-V

Distribution of the study patients by success of PCI

\begin{tabular}{lccc}
\hline Outcome & $\begin{array}{c}\text { Group- I* } \\
\text { No (percent) }\end{array}$ & $\begin{array}{c}\text { Group-II* }^{*} \\
\text { No (percent) }\end{array}$ & \\
\hline
\end{tabular}

Angiographic success $100(100 \%) \quad$ 100(100\%) $1.00\left(\right.$ NS* $^{*}$

$\begin{array}{llll}\text { Procedural success } & 129(97.7 \%) & 155(86.59 \%) & 0.01\left(\mathrm{~S}^{*}\right)\end{array}$

* Group I = hs-CRP $<3 \mathrm{mg} / \mathrm{L}$, * Group II = hs-CRP $\geq 3 \mathrm{mg} / \mathrm{L}, \mathrm{NS}=$ Not significant, $\mathrm{S}=$ Significant.

Angiographic success was same in two groups (100\%), procedural success was less in high hsCRP group 155(86.59\%) than in normal hsCRP group 129(97.7\%) which was statistically significant. (Table-V)
Table-VI

Multivariate analysis for predicting periprocedural myocardial injury assessed by CKMB elevation

\begin{tabular}{|c|c|c|c|c|}
\hline \multirow{2}{*}{$\begin{array}{l}\text { Variables of } \\
\text { interest }\end{array}$} & \multirow{2}{*}{$\begin{array}{c}\text { Univariate } \\
\text { analysis } \\
p \text { value }\end{array}$} & \multicolumn{3}{|c|}{ Multivariate analysis } \\
\hline & & OR & $95 \% \mathrm{Cl}$ of $\mathrm{OR}$ & $\mathrm{p}$ value \\
\hline age $(z$ & $0.62^{\text {ns }}$ & 1.73 & 0.83 & $0.16^{\mathrm{ns}}$ \\
\hline Fema & $39^{\text {ns }}$ & .41 & 38 & $.51^{\mathrm{ns}}$ \\
\hline itus & & 0.5 & 0. & \\
\hline mok & 0 & 1.2 & & 0. \\
\hline BMI & 0.5 & 1.01 & 0.8 & $0 . \varepsilon$ \\
\hline ion & & 0. & 0.4 & $0.88^{\mathrm{ns}}$ \\
\hline Elevated hsCRP & $0.001^{s}$ & 1.57 & $1.361-1.818$ & $0.001^{\mathrm{s}}$ \\
\hline
\end{tabular}

Binary logistic regression analysis of Odds Ratio for the traditional variables likely to affect periprocedural myocardial injury was done. All the above variables likely to be associated with periprocedural myocardial injury were entered into the model directly by univariate and multivariate regression analysis. Elevated hsCRP was found to be independent predictors for $\mathrm{PCl}$ related periprocedural myocardial injury. $(p=0.001, \mathrm{OR}=1.57)$ (Table VI).

\section{Discussion:}

This prospective, observational study was conducted in the Department of Cardiology, National Institute of Cardiovascular Disease (NICVD), Dhaka from January 2012 to December 2013. The main objective of the study was to evaluate the association of preprocedural hsCRP with periprocedural myocardial injury assessed by rise of CK-MB level, before and after PCl.

The mean $( \pm S D)$ age of the patients was $51 \pm 6.93$ years and $53 \pm 6.04$ years in group I and group II respectively, no significant difference was found between two groups. Most of the patients were in 5 th decade of life in both groups. In studies done by Herrman, et al. ${ }^{16}$ and de Winter, et al. ${ }^{17}$, study population were more elderly than our population and incidence were more in 7 th decade of life. This higher age range may be due to increased life expectancy in the western country. Male sex predominated in both groups. Male- female ratio was 2.5-2.7:1. No significant $(p=0.55)$ difference was found regarding sex distribution between two groups which correlates to study done by Herrmann, et al. ${ }^{16}$ and de Winter, et al. ${ }^{17}$ also showed male predominance in their study population. Among two groups, female was more in group II than group I, though the difference was not significant statistically $(p>05)$. Chew, et al. ${ }^{18}$ reported a higher prevalence of female gender in patients with elevated preprocedural hsCRP levels ( $>3 \mathrm{mg} / \mathrm{L}$ ). The Dallas Heart Study ${ }^{19}$ demonstrated higher CRP levels 
in both black and white women compared with men, even after adjustment for risk factors and medication use.

Regarding risk factors, patients with high preprocedural hsCRP had highest percentage of smoking (62\%),followed by diabetes mellitus (55\%), hypertension(45\%), dyslipidemia(36\%), and family h/o premature coronary artery disease(11\%). Similarly patients with normal preprocedural hsCRP group smokers were predominant (58\%), followed by diabetes mellitus (52\%) hypertension (42\%), dyslipidemia (32\%), and family history of premature coronary artery disease (9\%).Cross tab analysis found no statistically significant differences between two groups $(p>0.05)$. This distribution of risk factors in relation to hsCRP was consistent with those found by Herrmann, et al. ${ }^{16}$ and Chew, et al. ${ }^{18}$ Visser, et al 20 mentioned in their study that, the higher body mass index (BMI) is associated with higher CRP concentrations, even among young adults aged 17 to 39 years. These findings suggest a state of low-grade systemic inflammation in overweight and obese persons. In this current series it was observed that the BMI was higher in group II than in group I, although difference was not significant statistically $(p>0.05)$. A similar observation was made by Herrmann, et al ${ }^{16}$ in their study.

In this study, we included patient with chronic stable angina and unstable angina which was $46 \%$ and $54 \%$ respectively in group I and $48 \%$ and $52 \%$ respectively in group II. The difference was not significant statistically $(p>05)$. This was consistent with the study done by Chew, et al. ${ }^{18}$. Herrmann, et al. ${ }^{16}$ also found statistically insignificant difference between two groups as that of our study.

In this study, angiographic severity was assessed by vessel score, stenosis, lesion morphology and TIMI flow grading . Vessel score $(1.74 \pm 0.46$ vs. $2.24 \pm 0.78)$, stenosis score $(11.00 \pm 4.19$ vs. and $18.72 \pm 4.94)$ and multivessel disease (35\% vs. $42 \%$ ) were similar in both groups which were not statistically significant. This findings were consistent with study done by Herrmann, et al. ${ }^{16}$ found that multivessel disease were more in high hsCRP group, although not statistically significant as that of present study. Complex lesions (Type B \& C) were $31 \% \%$ in group I and $52 \%$ in group II respectively and the difference was statistically significant $(P<.05)$. This finding was consistent with study done by Herrmann ${ }^{16}$, Veselka, et al ${ }^{19}$, Chew, et al ${ }^{18}$.

Following $\mathrm{PCl}, \mathrm{CK}-\mathrm{MB}$ level was raised from baseline in both groups. In normal CRP group, there was no significant elevation of CK-MB level after PCl (Preprocedural vs. Post-procedural: $18.6 \pm 5.4$ vs. $29.1 \pm 5.6$ $\mathrm{mg} / \mathrm{L}, \mathrm{p}=0.64)$. In elevated CRP group, there was significant elevation of CK-MB level after PCl (Preprocedural vs. Post-procedural: $19.1 \pm 6.7$ vs. $52.46 \pm$ $9.4 \mathrm{mg} / \mathrm{L}, \mathrm{p}=0.01)$. The mean rise of CK-MB level was significantly higher in group II than group I (33.06 $\pm 11.62 \mathrm{U} /$ $L$ vs. $11.52 \pm 9.60 \mathrm{U} / \mathrm{L}, p=.01$ ). Also there was a positive linear correlation between preprocediral hsCRP level and rise of CKMB $(r=0.22)$ following procedure and it was statistically significant $(p<0.05)$. Periprocedural MI was found in $12(6.7 \%)$ patients in group II and 2(1.5\%) in group I, and the difference was significant statistically ( $p$ $<0.04$ ). Periprocedural myocardial necrosis was found in 7 (5.3\%) patients in group I and $38(21.2 \%)$ in group II, and the difference was significant statistically $(p$ $<0.01$ ). This relationship suggests that CRP may predict the risk of distal embolization or may play a direct role in augmenting microvascular inflammatory response after ischemic insult. In a recent meta-analysis Patti, et al. ${ }^{21}$ showed that, statin therapy reduced periprocedural MI most prominently in patients with elevated preprocedural CRP level. Saadeddin, et al. 22 reported that, preprocedural CRP elevation in $41 \%$ of 85 patients with stable angina and who undergoing $\mathrm{PCl}$, and this was associated with a 2.27 -fold higher risk of developing periprocedural myocardial injury. Although angiographic success was same in two groups (100\%), procedural success was less in high hsCRP group 155(86.59\%) than in normal hsCRP group 129(97.7\%) which was statistically significant $(p<0.5)$. This was not consistent with study by Herrmann, et al. ${ }^{16}$, where there was high procedural success rate (95\%) in high hs-CRP group. Use of statins, GPIIb/Illa inhibitor, more use of drug eluting stents might have some impact for such outcome.

Multivariate logistic regression analysis was done among traditional predictors of $\mathrm{PCl}$ outcome advanced age $(>50$ years), female gender, diabetes mellitus, BMI, hypertension, smoking, dylipidaemia, type $\mathrm{C}$ lesion, and hsCRP. After removing the effects of the all other variables, hs- CRP was found as as independent predictors of periprocedural myocardial injury during $\mathrm{PCl}$, assessed by CK-MB elevation with OR 1.57 and $p=0.001$.

In this study, we demonstrated that baseline levels of CRP predicted the incidence of periprocedural CKMB elevation following $\mathrm{PCl}$. Furthermore, a graded association between the extent of myocardial injury and CRP levels was present. Finally, CRP levels predicted periprocedural injury following $\mathrm{PCl}$ independently thus suggesting that a favoring effect on distal microembolization may be the main mechanisms 
underlying this association. The most common mechanisms of myocardial injury during $\mathrm{PCl}$ are distal embolization and side branch occlusion. Other significant causes include dissection, thrombus, no reflow/slow flow, or coronary perforation. Recent progress has been made for the identification of two main PMI patterns as well as for preventive strategies. type 1 (proximal type), which is in proximity to the target lesion of $\mathrm{PCl}$ may be due to side branch occlusion and type 2 (distal type), which is in the perfusion territory of the treated coronary artery due to structural and functional microvascular obstructions. ${ }^{23} 50$ to $75 \%$ of all the PMI is type 2 (distal type). The key factors which influence the incidence and magnitude of PMI could be broadly classified into patient factors, angiographic or lesion related factors, and procedural factors. Assessment of these factors prior to the intervention allows risk stratification for PMI. Patient factors implicated for higher incidence of PMI include older age, multi-vessel CAD, diffuse CAD, systemic atherosclerosis, pre-existing renal impairment, presence of anaemia, preprocedural C-reactive protein elevation, and pre-procedural raised white blood cell count. 24-29 The plaque burden, number of lesions, presence of bifurcation lesions, tortuosity, and calcification are all likely to influence myocardial injury during $\mathrm{PCl}^{30}$

\section{Conclusion:}

The inflammatory activity, as represented by hs-CRP level, is associated with procedure related microvascular injury as assessed by CK-MB elevation after PCI. Measurement of hs-CRP levels could provide a rationale for risk stratification before coronary intervention and may be a useful tool to target aggressive antiaggregatory or anti-inflammatory therapy to patients that are exposed to the highest risk for ischemic complications. As distal microembolization is a determinant of short and long term mortality after $\mathrm{PCl}$, specific strategies may be developed to minimize myocardial injury in subjects with elevated hs-CRP level.

\section{References:}

1. Detre K, Holubkov R, Kelsey S, et al.Percutaneous transluminal coronary angioplasty in 1985-1986 and 1977-1981. The National Heart, Lung, and Blood Institute Registry. N Engl J Med. 1988 Feb 4;318(5):265-70.

2. Togni M, Balmer F, Pfiffner D, Maier W, Zeiher AM, Meier B; Working Group, Interventional Cardiology and Coronary Pathophysiology, European Society of Cardiology.Percutaneous coronary interventions in Europe 1992-200. Eur Heart J. 2004 Jul;25(14): 1208-13.
3. Oh JK, Shub C, Ilstrup DM, Reeder GS. Creatine kinase release after successful percutaneous transluminal coronary angioplasty. Am Heart $\mathrm{J}$. 1985 Jun;109(6):1225-31.

4. Liuzzo G, Biasucci LM, Gallimore JR, et al. The prognostic value of $\mathrm{C}$-reactive protein and serum amyloid a protein in severe unstable angina. $N$ Engl J Med. 1994 Aug 18;331(7):417-24.

5. Zairis MN, Ambrose JA, Manousakis SJ, et al.; Global Evaluation of New Events and Restenosis After Stent Implantation Study Group. The impact of plasma levels of C-reactive protein, lipoprotein (a) and homocysteine on the long-term prognosis after successful coronary stenting: The Global Evaluation of New Events and Restenosis After Stent Implantation Study. J Am Coll Cardiol. 2002 Oct 16; 40(8):1375-82.

6. Abbate A, Biondi-Zoccai GG, Brugaletta S, Liuzzo G, Biasucci LM.C-reactive protein and other inflammatory biomarkers as predictors of outcome following acute coronary syndromes.SeminVasc Med. 2003 Nov;3(4):375-84.

7. Chan AW, Bhatt DL, Chew DP, et al.Relation of inflammation and benefit of statins after percutaneous coronary interventions. Circulation. 2003 Apr 8;107(13):1750-6.

8. Ioannidis JP, Karvouni E, Katritsis DG.Mortality risk conferred by small elevations of creatine kinase$M B$ isoenzyme after percutaneous coronary intervention.J Am Coll Cardiol. 2003 Oct 15; 42(8):1406-11.

9. Roe MT, Mahaffey KW, Kilaru R, et al.Creatine kinase-MB elevation after percutaneous coronary intervention predicts adverse outcomes in patients with acute coronary syndromes. Eur Heart J. 2004 Feb;25(4):313-21.

10. Nienhuis MB, Ottervanger JP, Bilo HJ, Dikkeschei $\mathrm{BD}$, Zijlstra F.Prognostic value of troponin after elective percutaneous coronary intervention: A metaanalysis.Catheter Cardiovasc Interv. 2008 Feb 15;71(3):318-24.

11. Simoons $M L$, van den Brand $M$, et al.Minimal myocardial damage during coronary intervention is associated with impaired outcome. Eur Heart $\mathrm{J}$. 1999 Aug;20(15):1112-9.

12. Thygesen K, Alpert JS, White HD; Joint ESC/ACCF/ AHA/WHF Task Force for the Redefinition of 
Myocardial Infarction. Universal definition of myocardial infarction. J Am Coll Cardiol. 2007 Nov 27;50(22):2173-95.

13. Sullivan DR, Marwick TH, Freedman SB. A new method of scoring coronary angiograms to reflect extent of coronary atherosclerosis and improve correlation with major risk factors. Am Heart J. 1990 Jun;119(6):1262-7.

14. Cannon CP, Battler A, Brindis RG, et al. American College of Cardiology key data elements and definitions for measuring the clinical management and outcomes of patients with acute coronary syndromes. A report of the American College of Cardiology Task Force on Clinical Data Standards (Acute Coronary Syndromes Writing Committee). J Am Coll Cardiol. 2001 Dec;38(7):2114-30.

15. Smith SC Jr, Feldman TE, Hirshfeld JW Jr, et al.; American College of Cardiology/American Heart Association Task Force on Practice Guidelines; ACC/AHA/SCAI Writing Committee to Update the 2001 Guidelines for Percutaneous Coronary Intervention.ACC/AHA/SCAI 2005 Guideline Update for Percutaneous Coronary Intervention-Summary Article: A Report of the American College of Cardiology/American Heart Association Task Force on Practice Guidelines (ACC/AHA/SCAI Writing Committee to Update the 2001 Guidelines for Percutaneous Coronary Intervention).J Am Coll Cardiol. 2006 Jan 3;47(1):216-35.

16. Herrmann J, Lennon RJ, Barsness GW, et al.High sensitivity C-reactive protein and outcomes following percutaneous coronary intervention in contemporary practice.Circ Cardiovasc Interv. 2012 Dec;5(6):783-90.

17. de Winter RJ, Koch KT, van Straalen JP, et al. Creactive protein and coronary events following percutaneous coronary angioplasty. Am J Med. 2003 Aug 1;115(2):85-90.

18. Chew DP, Bhatt DL, Robbins MA, et al.Incremental prognostic value of elevated baseline C-reactive protein among established markers of risk in percutaneous coronary intervention.Circulation. 2001 Aug 28;104(9):992-7.

19. Veselka J, Procházková S, Duchonová R, Homolová I, Tesar D.Relationship of C-reactive protein to adverse cardiovascular events in patients treated by percutaneous coronary intervention for stable angina pectoris. Int Heart J. 2005 Mar;46(2):195-204.

20. Visser M, Bouter LM, McQuillan GM, Wener MH, Harris TB.Elevated C-reactive protein levels in overweight and obese adults. JAMA. 1999 Dec 8;282(22):2131-5.
21. Patti G, Ricottini E, Nusca A, et al.Short-term, highdose Atorvastatin pretreatment to prevent contrastinduced nephropathy in patients with acute coronary syndromes undergoing percutaneous coronary intervention (from the ARMYDA-CIN [atorvastatin for reduction of myocardial damage during angioplasty_contrast-induced nephropathy] trial. Am J Cardiol. 2011 Jul 1;108(1):1-7.

22. Saadeddin SM, Habbab MA, Sobki SH, Ferns GA. Association of systemic inflammatory state with troponin I elevation after elective uncomplicated percutaneous coronary intervention. Am J Cardiol. 2002 Apr 15;89(8):981-3.

23. Herrmann J.Peri-procedural myocardial injury: 2005 update. Eur Heart J. 2005 Dec;26(23):2493-519.

24. Batchelor WB, Anstrom KJ, Muhlbaier LH, et al.Contemporary outcome trends in the elderly undergoing percutaneous coronary interventions: results in 7,472 octogenarians. National Cardiovascular Network Collaboration. J Am Coll Cardiol. 2000 Sep;36(3):723-30.

25. Kini A, Marmur JD, Kini S, et al. Creatine kinase-MB elevation after coronary intervention correlates with diffuse atherosclerosis, and low-to-medium level elevation has a benign clinical course: implications for early discharge after coronary intervention. J Am Coll Cardiol. 1999 Sep;34(3):663-71.

26. Marso SP, Gimple LW, Philbrick JT, DiMarco JP.Effectiveness of percutaneous coronary interventions to prevent recurrent coronary events in patients on chronic hemodialysis. Am J Cardiol. 1998 Aug 1;82(3):378-80.

27. McKechnie RS, Smith D, Montoye C, et al.; Blue Cross Blue Shield of Michigan Cardiovascular Consortium (BMC2). Prognostic implication of anemia on in-hospital outcomes after percutaneous coronary intervention. Circulation. 2004 Jul 20;110(3):271-7.

28. Goldberg A, Gruberg L, Roguin A, et al. Preprocedural C-reactive protein levels predict myocardial necrosis after successful coronary stenting in patients with stable angina. Am Heart $\mathrm{J}$. 2006 Jun;151(6):1265-70.

29. Gurm HS, Bhatt DL, Gupta R, Ellis SG, Topol EJ, Lauer MS. Preprocedural white blood cell count and death after percutaneous coronary intervention. Am Heart J. 2003 Oct;146(4):692-8.

30. vanGaal WJ, Ponnuthurai FA, Selvanayagam J, et al. The Syntax score predicts peri-procedural myocardial necrosis during percutaneous coronary intervention. Int J Cardiol. 2009 Jun 12;135(1):60-5. 